\title{
PERILAKU NARSIS PADA MEDIA SOSIAL DI KALANGAN REMAJA DAN UPAYA PENANGGULANGANNYA
}

\author{
Engkus $^{1}$, Hikmat $^{2}$, Karso Saminnurahmat ${ }^{3}$ \\ ${ }^{1,2}$ Fakultas Ilmu Sosial dan Ilmu Politik, Universitas Islam Negeri (UIN) Sunan Gunung Djati \\ J1. A.H. Nasution 105, Bandung, Jawa Barat, 40614, Indonesia \\ ${ }^{3}$ Prodi Ilmu Komunikasi, Fakultas Ilmu Sosial dan Ilmu Politik, UNIKOM \\ Jl. Dipatiukur 102 - 116, Bandung, Jawa Barat, Indonesia \\ No Tlp/ HP: ${ }^{10} 082216266677,{ }^{2} 081223615416,{ }^{3} 081224054859$ \\ E-mail: ${ }^{1}$ ekustyana16@gmail.com, ${ }^{2}$ hikmat_suganjar@yahoo.com, ${ }^{3}$ karsos_mm@yahoo.co.id
}

Naskah diterima tanggal 31Mei 2017, direvisi tanggal 16 September 2017, disetujui tanggal 18 September 2017

\section{NARCISSISTIC BEHAVIOUR ON SOCIAL MEDIA AMONG ADOLESCENTS AND PREVENTIVE EFFORTS POLICY}

\begin{abstract}
The phenomenon of narcissistic behavior among adolescents has become an epidemic disease of modern society. Narcissistic personality disorder is one of the several types of personality disorders. This study aims to map the behavioral profiles among narcissism in adolescents and the policy of preventive efforts. The theory used is Freud's psychoanalyst theory, the first person that uses the term narcissistic to describe people who showed himself an important person and possessed with the desire to get attention. The phase that all children go through before channeling their love for themselves to the significant person, so that the child is fixed in the narcissistic phase. Explanatory research through survey method is used to deepen this study. Based on the research results indicate that the behavior of adolescent narcissism among young students in the area of East Bandung in the medium category. Behavior that tends to increase along with the development of information and communication technology, indicates the need for vigilance. The preventive policy should be implemented in a comprehensive and sustainable manner with the involvement of stakeholders.
\end{abstract}

Keywords: narcissistic behavior, phenomenon, the behavioral profiles, policy of preventive efforts.

\begin{abstract}
Abstrak. Fenomena perilaku narsis di kalangan remaja telah menjadi sebuah epidemi penyakit masyarakat modern. Gangguan kepribadian narsistik merupakan jenis gangguan kepribadian. Penelitian ini bertujuan untuk memetakan profil perilaku narsisme di kalangan remaja dan kebijakan penanggulangannya. Teori yang digunakan yaitu teori psikoanalis Freud, yang pertama kali menggunakan istilah narcissistic untuk mendeskripsikan orang-orang yang menunjukkan bahwa dirinya orang penting secara berlebihan dan yang terokupasi dengan keinginan mendapatkan perhatian. Fase yang dilalui semua anak sebelum menyalurkan cinta mereka dari diri mereka sendiri kepada significant person, sehingga anak terfiksasi pada fase narsistik. Metode penelitian yang digunakan adalah metode penelitian survei dengan explanatory research. Berdasarkan hasil penelitian bahwa perilaku narsisme di kalangan remaja pelajar di kawasan Bandung Timur berada pada kategori sedang. Namun demikian bukan berarti dalam posisi aman, sebab perilaku mereka cenderung meningkat seiring dengan berkembangnya teknologi informasi dan komunikasi. Kebijakan penanggulangannya harus dilaksanakan secara komprehensif dan berkesinambungan dengan melibatkan berbagai stakeholders terkait.
\end{abstract}

Kata Kunci: fenomena perilaku narsis, profil perilaku, kebijakan penanggulangan. 


\section{PENDAHULUAN}

Pada masa usia transisi, remaja sudah mulai memiliki minat-minat tertentu seperti minat pada penampilan diri, remaja berusaha untuk dapat berpenampilan semenarik mungkin untuk mendapatkan pengakuan serta daya tarik.

Menurut Kernan dalam Santrock (1980) "Penampilan diri terutama di hadapan temanteman sebaya merupakan petunjuk yang kuat dari minat remaja dalam sosialisasi”. Remaja mengaktualisasikan minatnya terhadap penampilan diri secara berlebihan memiliki kecenderungan narsis, namun biasanya memiliki permasalahan dengan kepercayaan diri. Halgin \& Whitbourne (2010) menjelaskan bahwa mereka memiliki penghargaan yang berlebihan terhadap kehidupan mereka sendiri dan terus merasa kesal terhadap orang lain yang mereka rasa lebih sukses, cantik, dan cerdas. Narsisisme (dari bahasa Inggris) atau narsisme (dari bahasa Belanda) adalah perasaan cinta terhadap diri sendiri yang berlebihan. Orang yang mengalami gejala ini disebut narsisis (narcissist). Istilah ini pertama kali digunakan dalam psikologi oleh Sigmund Freud dengan mengambil dari tokoh dalam mitos Yunani, Narkissos (versi bahasa Latin: Narcissus), yang dikutuk sehingga ia mencintai bayangannya sendiri di kolam. Ia sangat terpengaruh oleh rasa cinta akan dirinya sendiri dan tanpa sengaja menjulurkan tangannya hingga tenggelam dan akhirnya tumbuh bunga yang sampai sekarang disebut bunga narsis (King, Johnson, Davison, et al., 2010).

Cakupan narsisme lebih luas, tidak hanya dipandang dari segi gaya hidup dan finansial, tetapi juga kekuasaan, prestasi, fisik, dan penampilan. Individu yang mempunyai kecenderungan narsisme lebih tertarik dengan hal yang hanya menyangkut dengan kesenangan pribadi. Hal ini juga memberikan pengaruh cukup besar dalam pergaulan sehari-hari dan biasanya tidak memiliki kepedulian terhadap perasaan orang lain.

Masa remaja dikatakan sebagai suatu masa penentu karena pada periode ini seseorang meninggalkan tahap kehidupan anak-anak, menuju ke tahap selanjutnya yaitu tahap kedewasaan. "Masa ini dirasakan sebagai suatu krisis karena belum adanya pegangan, sedangkan kepribadiannya sedang mengalami pembentukan" (Soekanto, 2010). Pendekatan psikodinamika dalam menangani orang dengan gangguan narsistik didasari oleh perspektif bahwa mereka kurang mengalami penghargaan pada masa anakanak untuk perilaku positif mereka (Halgin \& Whitbourne, 2010). Individu yang menampilkan perilaku narsisme dalam kehidupan mereka mengekspresikan rasa ketidakamanan pada masa anak-anak dan kebutuhan mereka untuk diperhatikan. Perasaan ketidakamanan diungkapkan secara berlawanan antara pengembangan jati diri yang salah dengan pemikiran yang tidak realistis mengenai kemampuan mereka.

Perilaku narsis di kalangan remaja cenderung meningkat saat ini. Seperti halnya terjadi di Bondowoso, Selasa (1/3/2016). Seorang remaja asal Situbondo bernama Lutfi Yudianto (16) terjatuh ke dasar jurang di tepi Jalan Raya Arak-arak, Kabupaten Bondowoso. Lutfi terpeleset saat selfie di tepi tebing dengan kedalaman 150 meter. Tewasnya Lutfie akibat terjatuh itu membuat sejumlah keluarga histeris. Tangis keluarga pecah saat mayat korban dibawa ke rumah duka, di Dusun Karang Malang Utara, Desa Kalianget Situbondo.

Saat kejadian, korban bersama saudaranya Samsul Bahrudin (16). Keduanya mengendarai motor Yamaha Mio pada Senin 29 Februari 2016 dan melakukan selfie di ketinggian jalan raya Desa Sumbercanting, Kecamatan Wringin Arak-arak Bondowoso. Keduanya memilih berhenti untuk mengabadikan keindahan pemandangan alam di kawasan itu. Usai memarkir motornya, Lutfi dan Samsul segera berfoto selfie. Nahas, saat itu posisi korban terlalu ke pinggir hingga mendekati bibir tebing.

Korban pun akhirnya terpeleset ke dasar jurang berkedalaman sekitar 150 meter. Samsul yang melihat kejadian itu langsung memberi tahu warga sambil berusaha mencari pertolongan. Saat berhasil dievakuasi, tubuh remaja itu ditemukan tersangkut di atas pohon 
di bawah tebing curam. Sejumlah personil Tim SAR Gabungan yang terdiri dari BPBD Situbondo, Bondowoso hingga Basarnassan Satpol PP Jember diterjunkan (Hartono, 2016).

Di Jakarta, seorang siswa SMP bernama Agus Firmansyah (12) tewas akibat jatuh dari lantai 5 (lima) sebuah gedung kosong di Koja, Jakarta Utara. Agus jatuh karena terpeleset saat sedang selfie bersama teman-temannya. Insiden itu terjadi di Kantor Imigrasi Jakarta Utara, Koja, Jakut, pada Rabu (4/5 2016) malam.

Kantor imigrasi tersebut kosong karena pembangunannya sudah lama terhenti. "Jadi anak-anak itu main-main ke gedung imigrasi itu sama teman-temannya, terus foto-foto selfie. Dia terpeleset lalu jatuh," kata Kapolsek Koja Kompol Supriatno (Amelia R., 2017).

Berdasarkan fenomena yang terjadi akhir-akhir ini yang cenderung semakin sering dan meningkat, sebagaimana diberitakan dari media baik media cetak maupun elektronik, begitu juga peneliti lain membahasnya dalam bentuk penelitian (sebagaimana penelitian di SMA 8 Malang), ahli lain juga mengungkapkan bahwa perubahan-perubahan masyarakat yang cepat cenderung turbulen dan disruptif (Hanggono, 2017), sehingga peneliti tertarik untuk melakukan penelitian terhadap profil perilaku narsisme peserta didik yang berada pada fase remaja di sekolah menengah pertama yang berada di wilayah Bandung Timur, agar dapat mengetahui serta memahami permasalahan yang terjadi pada remaja secara lebih mendalam.

Penelitian ini sebagai upaya awal guna mencegah perilaku narsisme di kalangan remaja tingkat Sekolah Lanjutan Tingkat Pertama (SLTP) seperti di Sekolah Menengah Pertama (SMP) dan Madrasah Tsanawiyah (MTS) yang ada di wilayah Bandung Timur yang akan dicari akar permasalahan serta langkah kebijakan penanggulangannya. Menjadi suatu kelainan kepribadian pada peserta didik dan implikasinya akan berpengaruh terhadap perilaku remaja sebagai generasi penerus bangsa.
Jika hal ini dibiarkan, tanpa ada upaya untuk melakukan penanggulangannya, hal ini berarti melakukan pembiaran terhadap remaja menjadi sosok yang egois, individualis, dan yang tidak memiliki kepedulian sekitarnya.

Rumusan masalah dalam penelitian ini: (1) Bagaimana profil perilaku narsisme di media sosial para remaja pelajar di kawasan Bandung timur?; (2) Bagaimana kebijakan penanggulangannya terhadap perilaku narsisme di kalangan remaja pelajar di kawasan Bandung Timur?.

Tujuan penelitian: (1) Untuk mendapatkan data tentang profil perilaku narsisme pada media sosial di kalangan remaja pelajar di kawasan Bandung Timur; (2) Untuk mengetahui bagaimana upaya penanggulangannya terhadap perilaku narsisme di kalangan remaja pelajar di kawasan Bandung Timur.

Manfaat penelitian: secara teoretis berpotensi memiliki manfaat (1) Memperkaya rumusan konsep, analitis, dan simpulan tentang perilaku narsisme pada media sosial di kalangan remaja; (2) Memperkaya pemahaman konseptual dengan memberikan penjelasan perilaku narsisme pada media sosial di kalangan remaja. Sedangkan secara praktis (1) Menjadi bahan pertimbangan dalam kebijakan bagi pemerintah dalam penanganan remaja; (2) Sebagai salah satu rujukan bagi peneliti berikutnya yang meneliti tentang perilaku narsisme di kalangan remaja.

\section{LANDASAN KONSEP}

\section{Review Penelitian Sejenis}

Terdapat penelitian yang dilakukan oleh Iswari Kartika Pratiwi yang berjudul: Hubungan Antara Kepercayaan Diri, Penghargaan Diri, dan Kecenderungan Perilaku Narsistik Remaja Perempuan Di SMA Negeri 8 Malang. Penelitian ini bertujuan untuk mengungkap hubungan antara tingkat kepercayaan diri dan menghargai diri dengan kecenderungan perilaku narsistik pada remaja perempuan di SMA Negeri 8 Malang. Penelitian ini bersifat deskriptif dan korelasional, pengambilan sampel dilakukan dengan teknik stratifikasi 
sampling. Teknik analisis data menggunakan analisis deskriptif, analisis korelasional, dan analisis regresi berganda (Pratiwi, 2010).

Berdasarkan hasil persentase, tingkat kepercayaan diri berada pada kategori tinggi, tingkat penghargaan diri berada pada kategori rendah, dan tingkat gangguan perilaku narsistik. Berada pada kategori tinggi. Kepercayaan diri dan penghargaan diri remaja banyak dipengaruhi oleh lingkungan sekitar, terutama keluarga dan teman sebaya. Adanya penerimaan dan pujian dari keluarga dan orang lain dapat mengembangkan kepercayaan diri dan penghargaan dirinya.

Ketika hal ini tidak dapat dikontrol dengan baik, maka remaja pelajar perempuan di SMA 8 Malang tersebut dapat mengalami gangguan perilaku narsistik. Gangguan perilaku narsistik sering menyerang remaja karena kurang kuatnya kontrol moral yang dimiliki oleh remaja. Oleh karena itu, diperlukan kontrol yang baik pada diri remaja agar dapat tetap mencintai dirinya namun tidak sampai mengalami gangguan perilaku narsistik.

Fenomena selfie dan perilaku narsisme di kalangan remaja pelajar dengan narsisme merupakan salah satu respon yang dibangun dari lingkungan sosialnya. Oleh karena itu, penelitian perilaku narsistik pada remaja perempuan di SMA Negeri 8 Malang ini, bertujuan untuk mengetahui hubungannya memotret diri sendiri (selfie) dengan narsisme dan respon yang muncul dari lingkungan sosialnya.

Teknik pengambilan data yang digunakan untuk melakukan penelitian di SMA 8 Malang adalah melalui wawancara kepada 30 narasumber remaja putri dan putra. Hasil penelitian tersebut mengungkapkan bahwa selfie yang dilakukan oleh remaja di SMA 8 Malang merupakan kegiatan memotret diri sendiri tanpa bantuan dari orang lain.

Sosialisasi terjadi melalui interaksi manusia. Para remaja di SMA 8 Malang belajar banyak dari orang-orang yang dianggap dekat seperti famili, sahabat, dan guru.

Tetapi juga belajar dari orang-orang yang dilihat di jalan, di televisi, di internet, film, dan majalah. Respon banyak mencontoh figure yang menjadi inspirasinya dalam bersikap, berpakaian, dan gaya berbicara. Remaja tersebut melihat dan menirukan gaya figure yang menjadi trend centernya seperti ikut mengunggah hasil fotonya ke media sosial. Lingkungan pun memberikan respon terhadap perilaku tersebut dengan pendapatnya masing-masing.

\section{Konsep Narsis dan Remaja}

Dalam kehidupan sehari-hari sering terlihat dan terdengar perilaku narsis. Narsis merupakan salah satu penyimpangan kepribadian mental seseorang di mana orang tersebut memiliki perasaan yang berlebihan bahwa dirinya lah yang paling penting, dan menginginkan untuk selalu dikagumi. Penyimpangan kepribadian adalah istilah umum untuk jenis penyakit mental seseorang, di mana pada kondisi tersebut cara berpikir, cara memahami situasi dan kemampuan berhubungan dengan orang lain tidak berfungsi normal. Kondisi itu membuat seseorang memiliki sifat yang menyebabkannya merasa dan berperilaku dengan cara-cara yang menyedihkan, membatasi kemampuannya untuk dapat berperan dalam suatu hubungan

Teori yang digunakan yaitu teori psikoanalis yang dipelopori Freud, sebagaimana dalam bukunya General Introduction to Psychoanalysis: Psikoanalisis Sigmund Freud yang diterjemahkan oleh Ira Puspitorini, dialah (Freud) orang yang pertama kali menggunakan istilah narcissistic untuk mendeskripsikan orang-orang yang menunjukkan bahwa dirinya orang penting secara berlebih-lebihan dan yang terokupasi dengan keinginan mendapatkan perhatian. Fase yang dilalui semua anak sebelum menyalurkan cinta mereka dari diri mereka sendiri kepada significant person, sehingga anak terfiksasi pada fase narsistik. Narsistik merupakan reaksi asumsi untuk menghadapi masalah-masalah self-worth yang tidak realistik sebagai hasil dari penurutan dan evaluasi yang berlebihan dari orang-orang yang signifikan (Freud, 2002).

Orang-orang yang narsis meyakini bahwa mereka adalah orang-orang yang lebih 
unggul daripada orang lain dan kurang bisa menghargai perasaan orang lain. Namun di balik rasa percaya dirinya yang teramat kuat, sebenarnya orang narsis memiliki penghargaan terhadap diri sendiri yang lemah, mudah tersinggung meskipun terhadap kritikan kecil. Sebenarnya kata narsis sendiri berasal dari seorang tokoh bernama Narciscus (bangsa Yunani) yang gemar mengagumi dirinya dengan bercermin di atas kolam. Hal inilah yang akhirnya menjadi dasar mengapa orang-orang yang terlalu berlebihan dalam mengagumi dirinya sendiri disebut narsis.

Narsisme memiliki spektrum yang lebar, dari ringan sampai berat. Sedikit narsisme adalah normal dan sehat. Setiap orang sesekali perlu mementingkan diri sendiri dan menjaga harga diri.

Masalah timbul bila kadarnya sudah berat sehingga merugikan diri sendiri dan hubungan dengan orang lain. Kondisi itu disebut gangguan kepribadian.

Gangguan kepribadian narsistik adalah pola berulang dari kesombongan, kecongkakan, dan egoisme yang menjauhkan dari pergaulan. Seseorang disebut memiliki gangguan kepribadian narsistik bila memiliki sedikitnya lima dari sembilan tanda berikut: (1) Melebih-lebihkan prestasi dan bakatnya, merasa dirinya seorang yang hebat; (2) Selalu membutuhkan kekaguman dan pujian orang lain; (3) Berfantasi tentang kesuksesan, kecantikan, kekuasaan, dan ketenaran tanpa batas; (4) Menganggap diri istimewa dan unik sehingga hanya sudi bergaul dengan orangorang lain yang berstatus tinggi atau berhubungan dengan institusi yang berkelas; (5) Merasa berhak untuk mendapatkan perlakuan istimewa atau orang lain harus selalu mengikuti kemauannya; (6) Mengeksploitasi orang lain untuk mendapatkan apa yang dia inginkan; (7) Tidak dapat mengenali atau berempati dengan perasaan dan kebutuhan orang lain; (8) Selalu iri hati dengan kesuksesan dan kepemilikan orang lain; (9) Berperilaku arogan, congkak, dan angkuh.

Banyak remaja yang menampilkan beberapa sifat narsis (terutama keegoisan dan ketidakpedulian terhadap perasaan orang lain), tetapi biasanya perilaku itu akan menghilang ketika tumbuh dewasa.

Remaja merupakan kelompok umur yang rentan dengan segala macam gangguan, karena pada usia remaja merupakan masa yang sedang kuat-kuatnya mencari jatidiri. Paling sedikit ada tiga hal yang harus diperhatikan, yakni: historik, narcisistik, dan anti sosial.

\section{Varian-varian Media Sosial}

Globalisasi adalah suatu proses yang menempatkan masyarakat dunia bisa menjangkau satu dengan yang lain atau saling terhubungkan dalam semua aspek kehidupan mereka, baik dalam budaya, ekonomi, politik, teknologi maupun lingkungan (Winarno, 2008).

Internet merupakan hasil globalisasi, merupakan salah satu teknologi canggih yang menghubungkan pengguna-penggunanya di seluruh dunia. Internet membantu para penggunanya dalam mendapatkan informasi dan berinteraksi dengan pengguna lainnya melalui media sosial. Media sosial merupakan saluran atau sarana pergaulan sosial secara online di dunia maya.

Indonesia merupakan salah satu negara yang masyarakatnya sebagai konsumen tertinggi terhadap media sosial. Media sosial yang dipakai masyarakat sangat beraneka ragam, di antaranya yaitu Facebook, twitter, path, line, dan sebagainya. Masing-masing media sosial memiliki fasilitas dan keunikan yang berbeda-beda.

\section{Perilaku Narsis dan Gangguan Kepribadian}

Keragaman kepribadian adalah apa yang membuat seseorang unik. Namun, terkadang kepribadian dapat memanifestasikan dirinya dalam cara yang tidak pantas dan merusak. Gangguan kepribadian mewakili berbagai perilaku, pola pikir, dan tanggapan emosional yang destruktif dan abnormal. Gangguan kepribadian cenderung terbentuk pada masa remaja atau awal masa dewasa dan bertahan sepanjang hidup seseorang.

Ada berbagai jenis gangguan kepribadian, dengan berbagai penyebab dan 
cara mengatasi, di mana sebagian gangguan kepribadian lebih mudah diatasi dibanding yang lain.

Beberapa penelitian menunjukkan bahwa setiap orang cenderung memiliki perilaku narsis, hanya kadarnya yang berbeda. Namun narsis akan berkembang menjadi perilaku narsis akut yang akan berimplikasi pada gangguan kepribadian. Jika hal ini dibiarkan cenderung akan membahayakan terhadap dirinya dan orang lain. Untuk lebih jelasnya, berikut ini akan dijelaskan tentang gangguan perilaku narsistik yang diduga disebabkan oleh faktor bawaan. Faktor psikososial, seperti pola hubungan keluarga yang patogenik, dan faktor sosiokultural, seperti munculnya sistem nilai dan pola perilaku tertentu yang jauh berbeda dari yang lazim berlaku di masyarakat akibat kondisi kemiskinan.

Misalnya, dalam bentuk standar yang sangat longgar tentang kejujuran, tanggung jawab sosial, dan sebagainya. Penderita aneka jenis gangguan ini biasanya sulit ditangani untuk ditolong. Mereka harus dipaksa. Usaha memberikan pertolongan biasanya lebih efektif bila dilakukan dalam lingkungan tertentu, misalnya di penjara atau pusat rehabilitasi lainnya.

Beck, dkk., dalam Widiyanti, Solehuddin \& Saomah (2017) berasumsi bahwa orang-orang dengan narsisme berpegang pada gagasan ketidakmampuan menyesuaikan diri sendiri, termasuk pandangan bahwa mereka adalah orang yang luar biasa yang pantas diperlakukan lebih baik dari pada manusia biasa. Di tengah gencarnya budaya hedonisme (menyandarkan status sosial dan kesuksesan pada ukuran materi harta benda dan kekuasaan) saat ini dapat menjadikan perilaku narsis semakin meluas dan pada akhirnya mengikis keimanan seseorang secara perlahan-lahan.

\section{Teori dan Kebijakan Penanggulangan}

Kebijakan merupakan hal yang sangat strategis dalam proses pencapaian tujuan. W. I. Jenkins dalam Wahab (2008), mengemukakan bahwa kebijakan adalah serangkaian keputusan yang saling berkaitan yang diambil oleh seorang aktor politik atau sekelompok aktor politik berkenaan dengan tujuan yang telah dipilih beserta cara-cara untuk mencapainya dalam satu situasi di mana keputusan-keputusan itu pada prinsipnya masih berada dalam batas-batas kewenangan kekuasaan dari aktor tersebut. Selanjutnya Siagian (1990) mengemukakan bahwa kebijakan adalah kegiatan keputusan strategis ditinjau dari sudut kepentingan pelestarian organisasi yang pada gilirannya akan memungkinkan mencapai tujuan yang telah ditetapkan.

Sejalan dengan hal tersebut di atas Edward III dan Sharkansky dalam Islamy (1997) mengatakan kebijakan publik itu dapat ditetapkan secara jelas dalam peraturanperaturan pemerintah ataupun berupa program-program dan tindakan-tindakan yang dilakukan pemerintah, untuk itu Dunn (2003) berpendapat: A policy system, or the overall pattern within which policies are made, involves inter-relationship among three element: public policy, policy stake holder and policy environment.

Selanjutnya Ripley dalam Nawawi
(2009) menyebutkan tahapan proses
kebijakan publik sebagai berikut: "Agenda, formulasi dan legitimasi kebijakan, implementasi kebijakan, evaluasi terhadap implementasi, kinerja, dan kebijakan baru". Kebijakan dalam kontek manajemen dijelaskan oleh Nugroho (2011) yang mengatakan: "Kebijakan publik adalah sebuah manajemen, mengagendakan pemahaman bahwa kebijakan publik harus dikendalikan. Jadi, daripada menggunakan frase evaluasi kebijakan, saya memilih untuk menggunakan istilah pengendalian kebijakan. Pengendalian kebijakan terdiri atas tiga dimensi, yaitu (1) Monitoring kebijakan atau pengawasan kebijakan; (2) Evaluasi kebijakan; (3) Pengganjaran kebijakan”.

\section{METODE PENELITIAN}

Metode penelitian yang digunakan adalah metode penelitian survei dengan explanatory research, Singarimbun \& Effendi (1994) mengemukakan bahwa penelitian survei adalah penelitian yang mengambil 
sampel dari satu populasi dan menggunakan kuesioner sebagai alat pengumpul data pokok.

Instrumen penelitian digunakan untuk mengukur nilai variabel yang diteliti dengan tujuan untuk mendapatkan hasil data kuantitatif secara akurat. Sugiyono (2016) menjelaskan bahwa angket sebagai teknik pengumpulan data sangat cocok untuk mengumpulkan data dalam jumlah besar. Dalam penelitian ini instrumen yang digunakan adalah angket mengenai narsisme yang diturunkan dari aspek-aspek yang dikembangkan oleh Vaknin dalam Widiyanti,
Solehuddin \& Saomah (2017) yang selanjutnya diturunkan menjadi indikator untuk kemudian dijabarkan menjadi butir pernyataan. Berikut merupakan kisi-kisi intrumen yang telah dirancang sebelum uji kelayakan. Hasil uji kelayakan instrumen pada Tabel 2 menunjukkan bahwa terdapat 45 item yang memenuhi untuk dijadikan sebagai item dalam intrumen dan 13 item dengan pertimbangan pada penggunaan kelayakan bahasa yang perlu direvisi dan tidak ada item yang perlu dibuang.

Tabel 1

Kisi-kisi Instrumen Penelitian Narsisme

\begin{tabular}{|c|c|c|c|c|}
\hline \multirow{2}{*}{ Aspek } & \multirow{2}{*}{ Indikator } & \multicolumn{2}{|c|}{ Item } & \multirow{2}{*}{ Total } \\
\hline & & $(+)$ & $(-)$ & \\
\hline \multirow{2}{*}{$\begin{array}{l}\text { Memiliki perasaan } \\
\text { grandiose (perasaan } \\
\text { megah) dan self- } \\
\text { important }\end{array}$} & Melebih-lebihkan prestasi dan bakat & 2,3 & 1 & 3 \\
\hline & $\begin{array}{l}\text { Tuntutan diri untuk diakui sebagai superior tanpa prestasi } \\
\text { sepadan }\end{array}$ & 5,6 & 4 & 3 \\
\hline \multirow{3}{*}{$\begin{array}{l}\text { Dipenuhi dengan } \\
\text { fantasi }\end{array}$} & Terobsesi akan ketenaran & 8,9 & 7 & 3 \\
\hline & Terobsesi dengan keindahan tubuh & 11,12 & 10 & 3 \\
\hline & Terobsesi dengan kemampuan seks & 14 & 13 & 2 \\
\hline \multirow{2}{*}{$\begin{array}{l}\text { Merasa diri adalah } \\
\text { individu yang khusus } \\
\text { dan spesial }\end{array}$} & Merasa diri paling hebat dibanding orang lain & 16,17 & 15 & 3 \\
\hline & $\begin{array}{l}\text { Hanya dapat bergaul dengan orang-orang khusus dengan } \\
\text { high status }\end{array}$ & 19,20 & 18 & 3 \\
\hline \multirow{4}{*}{$\begin{array}{l}\text { Memiliki kebutuhan } \\
\text { yang ekspresif untuk } \\
\text { dikagumi }\end{array}$} & $\begin{array}{l}\text { Membutuhkan kekaguman yang berlebihan dari orang } \\
\text { lain }\end{array}$ & 22,23 & 21 & 3 \\
\hline & Membutuhkan perhatian yang berlebihan dari orang lain & 25,26 & 24 & 3 \\
\hline & Ingin menjadi seseorang yang ditakuti & 28,29 & 27 & 3 \\
\hline & Ingin menjadi seseorang yang terkenal & 30,31 & 29 & 3 \\
\hline \multirow{2}{*}{$\begin{array}{l}\text { Mengeksploitasi } \\
\text { hubungan } \\
\text { interpersonal }\end{array}$} & Memanfaatkan orang lain untuk mencapai tujuan sendiri & 33 & 32 & 2 \\
\hline & Mengeksploitasi hubungan dengan teman & 35,36 & 34 & 3 \\
\hline \multirow{3}{*}{$\begin{array}{l}\text { Tidak memiliki rasa } \\
\text { empati }\end{array}$} & Tidak mau mengakui pilihan orang lain & 38,39 & 37 & 3 \\
\hline & Tidak dapat memahami perasaan orang lain & 41,42 & 40 & 3 \\
\hline & Tidak dapat memahami kebutuhan orang lain & 44 & 43 & 2 \\
\hline \multirow[t]{2}{*}{ Perasaan iri } & Merasa iri kepada orang lain & $46,47,48$ & 45 & 3 \\
\hline & Merasa bahwa orang lain iri terhadapnya (diri sendiri) & 50,51 & 49 & 3 \\
\hline \multirow[t]{2}{*}{$\begin{array}{l}\text { Berperilaku arogan dan } \\
\text { angkuh }\end{array}$} & $\begin{array}{l}\text { Merasa lebih tahu dibandingkan dengan orang lain } \\
\text { tentang suatu hal }\end{array}$ & 53 & 52 & 2 \\
\hline & Marah saat frustasi & 55,56 & 54 & 3 \\
\hline
\end{tabular}


Total

Sumber: Hasil Penelitian (diolah), 2016.

Tabel 2

Hasil Penimbangan Instrumen Perilaku Narsisme

\begin{tabular}{llc}
\hline $\begin{array}{l}\text { Hasil Penimbangan } \\
\text { Dosen Ahli }\end{array}$ & \multicolumn{1}{c}{ Nomor Item } & Jumlah \\
\hline Dipakai & $1,2,3,4,5,7,8,10,11,12,13,14,15,16,17,18,20,21,22,23,27,28$, & 45 \\
& $29,30,31,33,34,35,36,37,38,39,40,41,42,43,44,45,46,47,48,49$, & \\
& $50,51,52,53,54,55,56,57,58$ & 13 \\
Direvisi & $6,9,11,14,16,17,19,24,25,26,32,55,57$ & - \\
Dibuang & - &
\end{tabular}

Sumber: Hasil Penelitian (diolah), 2016.

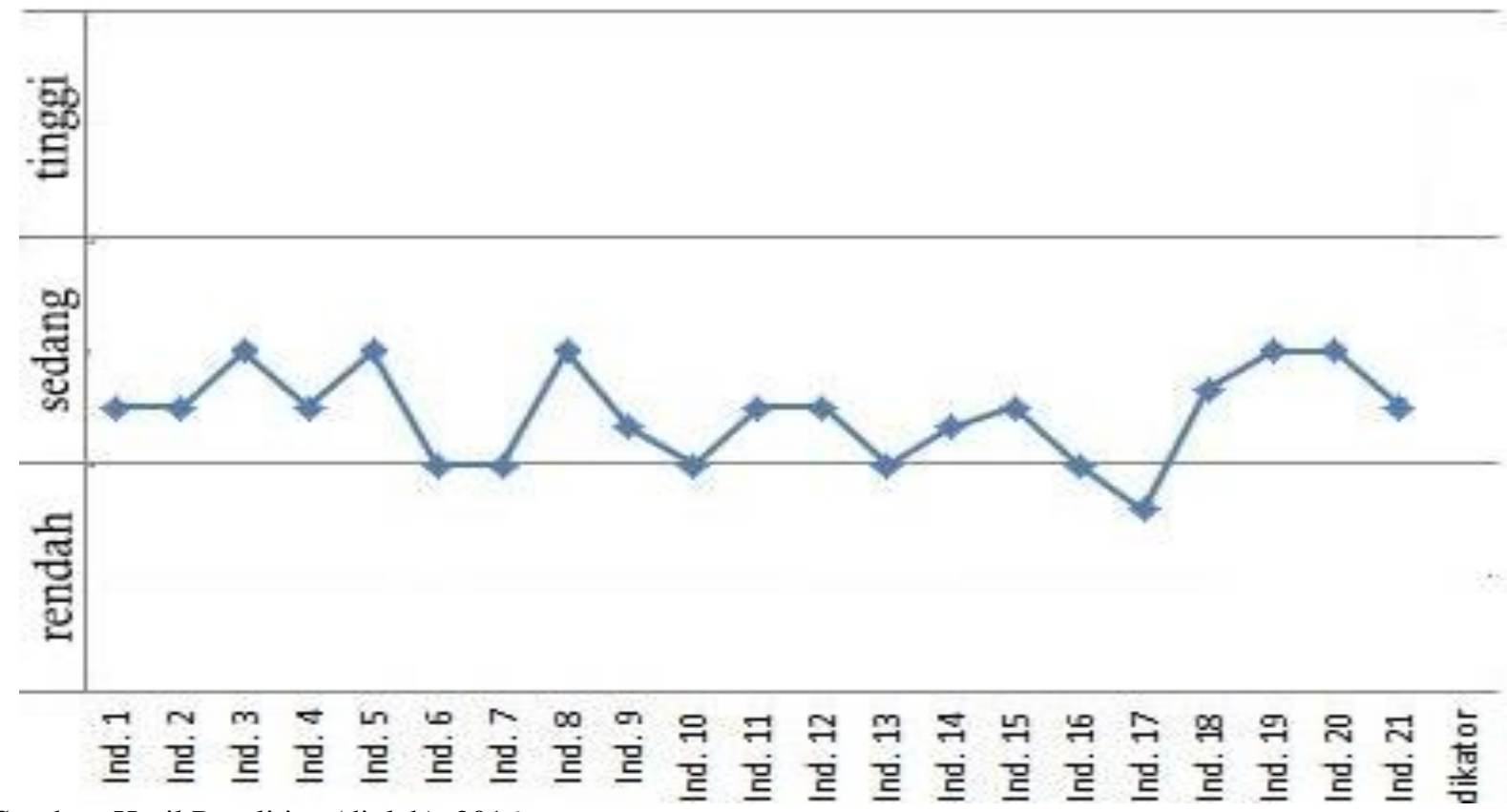

Sumber: Hasil Penelitian (diolah), 2016.

Grafik 1. Profil Narsisme Remaja Sekolahan di Kawasan Bandung Timur.

\section{HASIL PENELITIAN DAN PEMBAHASAN}

\section{Gambaran Umum Lokasi Penelitian}

Lokus penelitian adalah wilayah Bandung Timur yakni Kecamatan Cileunyi, Kecamatan Cilengkrang, Kecamatan Rancaekek, Kecamatan Solokanjeruk, Kecamatan Majalaya, dan Kecamatan Nagreg yang secara geografis berbatasan langsung dengan Kota Bandung dan dapat ditempuh hanya sekitar 30 menit menuju Kota Bandung. Sedangkan menuju pusat Kabupaten Bandung (Soreang) harus ditempuh dengan kendaraan paling cepat sekitar dua jam.
Pengaruh kota terhadap masyarakat Bandung Timur, secara langsung maupun tidak langsung masyarakat Bandung Timur cenderung memiliki karakteristik sebagai pribadi masyarakat kota namun masih memegang teguh nilai budaya masyarakat desa. Sikap perilaku itu secara signifikan dilihat perilaku kaum remaja pada tingkat Sekolah Menengah Pertama (SMP), Madrasah Tsanawiyah (MTs). Mereka cederung cepat menerima dan mengadopsi perilaku budaya kota. Salah satu perilaku yang paling menonjol di kalangan remaja pelajar adalah perilaku narsistik.

Penelitian yang dilakukan secara aksidental, tanpa ada rekayasa atau tindakan 
perlakuan terhadap responden. Angket langsung diberikan kepada responden ketika mereka sekolah atau di tempat-tempat strategis tempat berkumpul (nongkrong) para remaja yang ada di Kawasan Bandung Timur.

\section{Hasil Penelitian}

Profil narsisme merupakan gambaran tingkat narsisme yang terdiri dari setiap indikator yang diungkap. Pada indikator narsisme, terdapat sebanyak 21 indikator. Profil narsisme remaja sekolah yang berada di kawasan Bandung Timur dapat dilihat pada Grafik 1. Grafik di atas mendeskripsikan bahwa perolehan hasil yang didapatkan adalah tidak terdapat indikator yang termasuk ke dalam kategori tinggi, namun sebagian besar indikator termasuk ke dalam kategori sedang. Terdapat 15 indikator yang berada pada kategori sedang yakni indikator 1, indikator 2, indikator 3, indikator 4, indikator 5 , indikator 8 , indikator 11 , indikator 12 , indikator 14, indikator 15 , indikator 18 , indikator 19, indikator 20, dan indikator 21. Sementara sisanya adalah 6 indikator yang termasuk ke dalam kategori rendah, yakni indikator 6, indikator 7, indikator 10, indikator 13 , indikator 16 , indikator 17 , dan indikator 18.

Dari ketiga kategori berikut ini akan peneliti uraikan secara berurutan bahwa yang termasuk kategori tinggi (tidak ada) adalah perilaku selain sensasional, kebanggaan untuk diekspos, dan berlebihan; kategori sedang (indikator 2, 3, 4, 5, 8, 11, 12, 14, 15, 18, 19, 20, dan 21) yakni ciri utamanya sensasional, tidak ada rasa bangga untuk diekspos; dan kategori rendah (indikator 6, 7, 10, 13, 16, 17, dan 18) yakni ciri utama perilakunya masih ikut-ikutan, asal-asalan mengikuti trend.

$$
\text { Berdasarkan hasil penelitian }
$$

menunjukkan bahwa perilaku narsisme remaja di kalangan remaja yang berada di kawasan Bandung Timur berada pada katagori sedang. Namun keadaan itu bukan berarti remaja dalam posisi aman, sebab perilaku mereka cenderung meningkat seiring dengan pengaruh perkembangan teknologi informasi dan komunikasi. Hasil penelitian juga mengungkap bahwa kebijakan (policy) penanggulangannya belum dilaksanakan secara komprehensif dan berkelanjutan yang melibatkan berbagai pihak antara lain: pihak sekolah, orangtua, peserta didik, tokoh ulama, tokoh masyarakat serta pimpinan formal lainnya.

\section{Pembahasan}

Perilaku narsisme berkaitan dengan berbagai masalah dan konsekuensi dengan fokus pada konsekuensi interpersonal, patologi dan implikasi kebijakan (policy) dalam penanganannya. Perilaku narsis yang terobsesi oleh delusi fantastis keagungan dan keunggulan hingga akhirnya terjadilah persaingan. Mereka sering menjadikan diri mereka sebagai yang teratas. Tetapi meskipun orang-orang narsis tidak memiliki kemampuan yang cukup unggul, mereka akan berusaha, berjuang, belajar, membuat, berpikir, mendesain, dan bersekongkol untuk mendapatkan tujuan yang mereka inginkan sebagai individu yang paling superior.

Narsisme dikaitkan dengan agresivitas dalam mengritik harga diri baik dalam bentuk penghinaan, kemarahan maupun perilaku lain yang kurang terkontrol.

Peningkatan diri atau self-enhancement sebagai perilaku narsisme jika terjadi karena kesalahan dalam menentukan suatu sikap, atau kecenderungan untuk memaksakan kesuksesan tetapi menyalahkan situasi atau orang lain ketika mengalami kegagalan. Dalam hal ini self-enhancement, memberikan suatu keyakinan sebagai individu yang lebih dari pada orang lain. Sikap maupun perilaku narsisme terbukti berkaitan dengan distorsi kognitif. Seseorang yang berperilaku narsis memiliki rasa percaya diri yang tinggi, dengan melebih-lebihkan pengetahuan dan gagal, karena tidak bisa belajar dari pengalaman yang ada.

Individu yang membutuhkan penghargaan akan menuntut lingkungan untuk dapat mengakui dirinya sebagai individu yang unik dan superior. Untuk itu, narsis biasanya lebih banyak menunjukkan identitas diri kepada orang lain guna mendapatkan pengakuan dan kekaguman dari orang lain. Perilaku narsisme di kalangan remaja cenderung dilakukan sebagai aktualisasi diri tentang eksistensi diri agar 
dilihat orang lain. Kecenderungan untuk dilihat orang-orang lain tersebut biasanya dipublikasikan melalui media sosial.

Karakteristik yang khas pada perilaku narsisme adalah leadership (autory) yaitu keinginan menjadi pemimpin atau seseorang yang berkuasa. Konteks menjadi seorang pemimpin dalam indikator ini adalah peserta didik menjadi seorang ketua kelas maupun ketua Organisasi Siswa Intra Sekolah (OSIS) di sekolah. Selain itu juga, perilaku yang ditampilkan adalah terobsesi untuk menjadi juara kelas namun malas untuk belajar. Artinya bahwa peserta didik memiliki keinginan untuk menjadi seseorang yang unggul namun tidak disertai dengan prestasi yang sepadan.

Meskipun terdapat 9\% peserta didik yang berada pada kategori tinggi, pada indikator ini peserta didik yang berada pada kategori rendah menunjukkan persentase tertinggi yakni 52\%. Kategori rendah menunjukkan bahwa peserta didik dapat mempertimbangkan keinginan jika tidak sesuai dengan kemampuan yang dimiliki dengan menunjukkan sikap realistis. Sementara untuk kategori sedang adalah sebanyak 49\%, kategori sedang menunjukkan bahwa peserta didik berada di antara kategori tinggi dan rendah artinya bahwa peserta didik bisa saja memiliki keinginan untuk menjadi seorang pemimpin maupun juara kelas namun tidak memaksakan diri untuk bisa mencapainya. Indikator ketiga adalah memiliki fantasi akan ketenaran. Hasilnya menunjukkan peserta didik yang termasuk dalam kategori rendah merupakan jumlah terendah di antara kategori lainnya yakni dengan persentase $3 \%$. Indikator ini diasumsikan sebagai upaya individu untuk mendapatkan pengakuan dari orang-orang di sekitarnya.

Di kalangan remaja peserta didik yang berada di Kawasan Bandung Timur, berada pada kategori rendah menunjukkan tidak adanya fantasi akan ketenaran karena fantasi adalah sebuah khayalan sementara untuk peserta didik yang berada pada kategori tinggi menunjukkan adanya respon positif terhadap indikator ini. Hasil persentasi menunjukkan untuk kategori tinggi adalah $23 \%$ dan untuk kategori sedang adalah $74 \%$. Kategori tinggi berarti bahwa peserta didik memiliki daya khayal yang tinggi untuk menjadi seorang yang populer di sekolah dan mengharapkan agar orang lain mengakui prestasi yang ia miliki. Indikator keempat yakni terobsesi akan keindahan tubuh, perolehan hasilnya terdapat $14 \%$ peserta didik yang termasuk ke dalam kategori tinggi. Hal ini mendeskripsikan bahwa peserta didik memiliki kriteria akan kecantikan atau ketampanan, pada indikator ini perilaku yang ditampilkan adalah keinginan untuk menjadi yang paling cantik atau tampan serta adanya kesenangan untuk melihat kecantikan atau ketampanan dengan bercermin. Berdasarkan hasil penelitian ini juga menunjukkan, bahwa faktor lainnya yang dapat memengaruhi narsisme adalah sosio cultural, hal ini didasari adanya anggapan masyarakat dalam lingkungan sosial tertentu mengenai tubuh ideal dan wajah menarik.

Sementara penyebab gangguan kepribadian narsistik ini sendiri sampai saat ini belum diketahui secara pasti. Namun beberapa hasil penelitian menujukkan gangguan kepribadian narsistik ini terjadi karena kegagalan selama masa perkembangan, harapan yang terlalu tinggi, keinginan untuk diperhatikan maupun cara berpikir yang salah. Untuk pengobatannya sendiri sampai saat ini belum ditemukan obat secara medis yang bisa digunakan untuk mengobati gangguan kepribadian narsistik ini. Namun pengobatan tetap bisa dilakukan dengan terapi, yakni Binaural Beats Narsisistic Therapy. Binaural BeatsNarsisistic Therapy akan memberikan stimulus positif pada otak yang akan memberikan ketenangan dan menghilangkan gangguan kepribadian narsistik dengan mengembalikan fungsi otak serta mengubah cara kerja otak menjadi lebih baik lagi. Binaural Beats - Narsisistic Therapy telah melewati proses penelitian selama bertahuntahun dan terbukti efektif dalam mengatasi berbagai gangguan kerpibadian, termasuk gangguan kepribadian narsistik.

Berbeda dengan pendekatan sosiologis penyimpangan itu disebut dengan isitilah delinkuensi. "delinkuensi anak-anak yang 
terkenal di Indonesia adalah masalah cross boys dan crossgirl yang merupakan sebutan bagi anak-anak muda yang tergabung dalam suatu ikatan/organisasi formal atau semi formal dan yang mempunyai perilaku yang kurang/tidak disukai oleh masyarakat pada umumnya. Delinkuensi (delinquency) anak-anak di Indonesia meningkat pada tahun 1956 dan 1958 dan juga pada 1968-1969, hal mana sering disinyalir dalam pernyataan-pernyataan resmi pejabat maupun, petugas-petugas penegak hukum. Juga terjadi perkelahian antara siswa-siswa pelbagai sekolah di Jakarta dan kota-kota lain.

Delinkuensi anak-anak meliputi pencurian, perampokan, pencopetan, penganiayaan, pelanggaran susila, penggunaan obat-obat perangsang, dan mengendarai mobil (atau kendaraan bermotor lainnya) tanpa mengindahkan norma-norma lalu lintas. Memang, apabila dibandingkan dengan delinkuensi anak-anak di negaranegara lain, masalah tersebut belum merupakan masalah gawat di Indonesia. Akan tetapi hal ini bukan berarti boleh lengah. Sorotan terhadap delinkuensi anak-anak di Indonesia terutama tertuju pada perbuatanperbuatan pelanggaran yang dilakukan oleh anak-anak muda dari kelas-kelas sosial tertentu.

Perbuatan-perbuatan seperti mengendarai kendaraan bermotor secara sewenang-wenang, penggunaan obat-obat perangsang, pengedaran bahan-bahan pornografi, hanya dapat dilakukan oleh mereka yang berasal dari golongan mampu. Perlu diadakan penelitian terhadap delinkuensi anak-anak terutama yang berasal dari blighted area yaitu wilayah kediaman dengan tingkat disorganisasi tinggi. Beberapa upaya pencegahan terhadap perilaku narsis yang perlu dilakukan antara lain: usaha pembinaan pribadi remaja sejak masih dalam kandungan melalui ibunya. Setelah lahir, maka anak perlu diasuh dan dididik dalam suasana yang stabil, menggembirakan serta optimisme. Pendidikan dalam lingkungan sekolah. Sekolah sebagai lingkungan kenakalan dan sebagai tempat pembentukan anak didik memegang peranan penting dalam membina mental, agama pengetahuan dan keterampilan anak-anak didik. Kesalahan dan kekurangan- kekurangan dalam tubuh sekolah sebagai tempat mendidik, bisa menyebabkan adanya peluang untuk timbulnya kenakalan remaja. Pendidikan di luar sekolah dan rumah tangga. Dalam rangka mencegah atau mengurangi timbulnya kenakalan remaja akibat penggunaan waktu luang yang salah, maka pendidikan di luar dua instansi tersebut di atas perlu ditingkatkan. Disamping perbaikan lingkungan dan kondisi sosial.

Perkembangan agama pada masa anak, terjadi melalui pengalaman hidupnya sejak kecil, dalam keluarga, di sekolah dan dalam masyarakat lingkungan. Semakin banyak pengalaman yang bersifat agama, (sesuai dengan ajaran agama) dan semakin banyak unsur agama, maka sikap, tindakan, kelakuan, dan caranya menghadapi hidup akan sesuai dengan ajaran agama. Kedua, orang tua harus mengerti dasar-dasar pendidikan. Zakiah Daradjat dalam Makmun, (2007), menyatakan bahwa pendidikan dan perlakuan yang diterima oleh anak sejak kecil merupakan sebab-sebab pokok dari kenakalan anak-anak, maka setiap orang tua haruslah mengetahui dasar-dasar pengetahuan, minimal tentang jiwa anak dan pokok-pokok pendidikan yang harus dilakukan dalam menghadapi bermacam-macam sifat anak. Untuk membekali orang tua dalam menghadapi persoalan anak-anaknya yang dalam umur remaja, orang tua perlu pengertian sederhana tentang ciri-ciri remaja atau psikologi remaja.

Terkadang seseorang memandang narsisme merupakan hal yang biasa dan tidak perlu mendapatkan penanganan. Hal ini mungkin ada benarnya bila penderita narsis tersebut belum tergolong ke dalam tingkat yang parah atau belum mengganggu kenyamanan orang lain. Namun, ada kalanya tanpa disadari penyimpangan seperti narsis tersebut mengalami perkembangan ke arah yang lebih buruk, dan dianggap sudah mengganggu baik bagi orang lain maupun bagi si penderita itu sendiri. Pada saat seperti itulah penderita narsis perlu segera ditangani dan diatasi.

Penanganan narsis atau obat bagi penderita narsis tentunya juga harus disesuaikan dengan tingkat keparahannya. 
Treatment atau penanganan yang biasanya dilakukan yaitu melalui terapi psikologis. Ketika seorang penderita narsis sudah terjebak dalam pemikiran bahwa segalanya harus sempurna (perfect) dan semuanya tidak boleh ada yang salah, maka hal tersebut bisa menimbulkan masalah bagi kehidupan dan lingkungan sekitarnya. Dampaknya hubungan di sekolah, tempat kerja, atau hubunganhubungan interaksi yang lain menjadi sangat terganggu. Jika dibiarkan berlarut-larut, hal ini tentu akan membuat penderita menjadi tidak bahagia dan semakin bingung dengan segala bentuk emosi yang berkecamuk dalam dirinya. Orang-orang di sekitarnya pun pastinya tidak akan merasa bahagia dan nyaman. Akibat terburuknya bila penderita dijauhi, maka penderita akan merasa kebutuhan interaksinya dengan manusia lain tidak terpenuhi. Pada saat seperti inilah penderita narsis perlu mendapatkan pengobatan melalui penanganan secara psikologis.

Remaja yang masih mencari jati diri biasanya memang mengalami gejala-gejala seperti narsisme, yang menjadi tidak wajar adalah apabila gejala-gejala narsisme tersebut terus melekat dalam diri sampai dewasa. Hal ini lah yang nantinya akan berkembang menjadi suatu kelainan kepribadian. Pada tingkatan yang cukup parah, bisa terjadi berbagai komplikasi yang menyertai kehidupan penderita narsis, antara lain: adanya perilaku narsis yang dialami oleh remaja.

Berdasarkan hasil penelitian mengungkapkan bahwa profil narsisme di wilayah Bandung Timur diklasifikasikan menjadi tiga kategori, yaitu: pertama, kategori tinggi perilaku narsisme di kalangan remaja cenderung menunjukkan perilaku yang berlebihan, menganggap dirinya sebagai seseorang yang berharga, kebutuhan untuk dikagumi, grandiosity, dan mementingkan diri sendiri.

Perilaku narsisme biasanya terobsesi untuk dapat memuaskan hasrat dalam kekayaan, kekuatan, dan kecantikan atau ketampanan yang ada pada diri remaja pelajar di Kawasan Bandung Timur. Kedua, Berdasarkan hasil penelitian menunjukkan bahwa tingkat narsisme pada remaja sekolah yang berada di Kawasan Bandung Timur termasuk dalam kategori sedang, peserta didik memiliki kecenderungan dalam keterpusatan diri namun masih dapat ditangani oleh dirinya sendiri sehingga tidak memunculkan konsep diri megah (grandiosity). Pada umumnya peserta didik, memiliki keinginan untuk diakui oleh orangorang di sekitarnya terutama teman sebaya sehingga perilaku-perilaku yang cenderung mengarah pada narsisme terkadang terjadi sebagai suatu bentuk dari pengaruh lingkungan. Meskipun demikian, peserta didik yang termasuk ke dalam kategori ini perlu memiliki self-control yang baik agar perilaku yang cenderung mengarah pada narsisme dapat dikelola dengan baik. Secara umum, tingkat narsisme remaja pelajar berada di Kawasan Bandung Timur pada kategori sedang. Hal ini dideskripsikan pada setiap indikator yang termasuk ke dalam kategori sedang. Jika dilihat dari distribusi narsisme per individu maka diketahui dari 137 peserta didik yang dijadikan sebagai responden dalam $53 \%$ berada pada kategori sedang. Ketiga, perilaku narsisme yang tidak memiliki kecenderungan perilaku narsisme atau berada pada kategori rendah merupakan peserta didik yang sudah memiliki penghargaan diri yang tinggi. Perilaku narsisme timbul akibat dari adanya perasaan tidak nyaman terhadap diri sendiri dan rendahnya harga diri sehingga menampilkan perilaku narsisme untuk mendapatkan kenyaman diri serta penghargaan dari orang lain.

\section{PENUTUP}

\section{Simpulan}

Berdasarkan hasil penelitian, menunjukkan bahwa profil perilaku narsisme di kalangan remaja yang berada di Kawasan Bandung Timur berada pada kategori sedang, namun bukan berarti dalam posisi aman, sebab perilaku mereka cenderung meningkat.

Kebijakan tindakan pecegahan yang dilaksanakan secara komprehensif dan berkelanjutan terutama melalui pembinaan akhlakulkarimah terhadap remaja di Kawasan 
Bandung Timur menjadi sangat penting. Pembinaan akhlak untuk segera dilakukan antara lain: oleh pihak sekolah, dapat dilakukan oleh semua tenaga pendidik dan tenaga kependidikan, mulai dari kepala sekolah, wakil kepala sekolah, guru, dan termasuk pegawai/karyawan untuk menjadi teladan karena sekolah merupakan agent of excellent bagi remaja peserta didiknya.

\section{Saran}

Untuk meminimalisir terhadap perilaku narsis di kalangan remaja di kawasan Bandung Timur perlu kebijakan pemerintah yang ditangani secara komprehensif dari perbagai pihak antara lain: pihak sekolah untuk segera meningkatkan pembinaan secara terkoodinasi antara pimpinan sekolah seperti kepala sekolah, wakil kepala sekolah guru $\mathrm{BP} / \mathrm{BK}$, guru agama, guru PPKN dan masyarakat serta pihak terkait lainnya untuk bersama-sama menanggulangi masalah tersebut agar tidak masuk pada perilaku narsis akut karena akan membahayakan bagi masa depan peserta didik yang bersangkutan.

Kepada orang tua remaja pelajar di Kawasan Bandung Timur, segera melakukan pendekatan-pendekatan untuk mencegahnya agar anak remaja tidak terjebak dalam perilaku narsis akut atau perilaku berlebihan karena akan berpengaruh terhadap perilaku yang lebih berbahaya, yang pada giliran lain akan tidak menguntungkan bagi diri anak remaja itu sendiri atau lingkungannya di mana remaja itu berada. Perlu ada suatu kebijakan penanganan yang serius dan berkelanjutan dari semua pihak untuk melakukan penanggulangan yang lebih berat akibat dari perilaku narsis di kalangan remaja sekolah yang ada di Kawasan Bandung timur.

Kebijakan pemerintah dalam penanganan terhadap perilaku narsis di kalangan remaja sekolah di Kawasan Bandung Timur perlu dilakukan dengan kerja sama yang komprehensif dari semua pihak antara lain pihak sekolah, orang tua remaja pelajar, aparat terkait, lembaga sosial dan lembaga sosial keagamaan seperti MUI, NU Persis, Muhammadiyah, dan sebagainya. Mereka memiliki peran penting untuk melakukan suatu penanganan dan penanggulangan terhadap bahaya akibat perkembangan teknologi informasi dan komunikasi.

Kegiatan tersebut dilakukan secara terarah, dan terkoordisasi dari semua pihak, melalui suatu kegiatan bersama misalnya, diskusi pembinaan akhlaq, moral dan budaya lokal, ceramah atau pengajian remaja.

\section{DAFTAR PUSTAKA}

Amelia R., M. (2017) Asyik Selfie, Siswa SMP Tewas Terjatuh dari Lantai 5 Gedung Kosong di Koja. [Online]. 2017. Detik.com. Available from: https://news.detik.com/berita/3204210/asyik -selfie-siswa-smp-tewas-terjatuh-dari-lantai5-gedung-kosong-di-koja [Accessed: 20 September 2017].

Dunn, W.N. (2003) Pengantar Analisis Kebijakan Publik. 2nd edition. Yogyakarta, Gadjah Mada University Press.

Freud, S. (2002) Sigmund Freud A General Introduction to Psychoanalysis. Yogyakarta, Ikon Teralitera.

Halgin, R.P. \& Whitbourne, S.K. (2010) Psikologi Abnormal. Jakarta, Salemba Humanika.

Hanggono, A.T. (2017) Dies Natalis ke 60 Universitas Padjadjaran. Harian Umum Pikiran Rakyat. 1,12.

Hartono, I. (2016) Asyik Selfie, Pelajar SMA Situbondo Ini Terpeleset dan Tewas di Jurang Sedalam 100 Meter. [Online]. 2016. SURYA.co.id. Available from: http://surabaya.tribunnews.com/2016/03/01/ asyik-selfie-pelajar-sma-situbondo-initerpeleset-dan-tewas-di-jurang-sedalam-100meter [Accessed: 12 August 2017].

Islamy, M.I. (1997) Prinsip-Prinsip Perumusan Kebijakan Negara. Jakarta, Bumi Aksara.

King, A.M., Johnson, S.L., Davison, G.C. \& Neale, J.M. (2010) Abnormal Psychology. 11 th edition. John Wiley \& Sons, Inc.

Makmun, S.A. (2007) Psikologi Kependidikan. Bandung, Remaja Rosdakarya.

Nawawi, I. (2009) Public Policy: Analisis, Strategi, Advokasi dan Praktek. Jakarta, Putra Media Nusantara.

Nugroho, R. (2011) Public Policy. Jakarta, Gramedia.

Pratiwi, I.K. (2010) Hubungan Antara Kepercayaam Diri, Penghargaan Diri, dan Kecenderungan Perilaku Narsistik Remaja Perempuan. Universitas Negeri Malang. 
Santrock, J.W. (1980) Psikologi Perkembangan. Jakarta, Erlangga.

Siagian, S.P. (1990) Filsafat Administrasi. Jakarta, Haji Masagung.

Singarimbun, M. \& Effendi, S. (1994) Metode Penelitian Survei. Jakarta, LP3ES.

Soekanto (2010) Sosiologi Suatu Pengantar. Jakarta, Rajawali Pers.

Sugiyono (2016) Metode Penelitian Kuantitatif dan RND. Bandung, Alfabeta.

Wahab, S.A. (2008) Analisis Kebijaksanaan: dari Formulasi ke Implementasi Kebijakan. Jakarta, Bumi Aksara.

Widiyanti, W., Solehuddin, M. \& Saomah, A. (2017) Profil Perilaku Narsisme Remaja Serta Implikasinya Bagi Bimbingan dan Konseling. Indonesian Journal of Educational Counseling. [Online] 1 (1), 1526. Available from: http://ijec.ejournal.id/index.php/counseling/a rticle/view/3.

Winarno, B. (2008) Globalisasi: Peluang atau Ancaman Bagi Indonesia. Jakarta, Erlangga. 